\title{
Author Correction: Visualization of mucosal field in HPV positive and negative oropharyngeal squamous cell carcinomas: combined genomic and radiology based 3D model
}

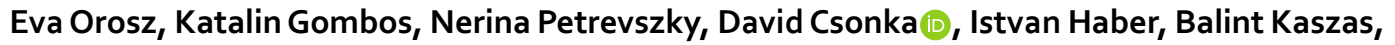
Arnold Toth, Krisztian Molnar, Krisztina Kalacs, Zalan Piski, Imre Gerlinger, Andras Burian, Szabolcs Bellyei \& Istvan Szanyi

Correction to: Scientific Reports https://doi.org/10.1038/s41598-019-56429-4, published online 08 January 2020

In this Article, the legend of Figure 1 is incorrect:

"Squamous cell epithelium negative for p16 immunohystochemical staining at 40x magnification. Histological section originates from a grade 2 oropharyngeal wall squamous cell carcinoma."

should read:

"Squamous cell epithelium positive for p16 immunohistochemical staining at 40x magnification. Histological section originates from a grade 3 tonsillar squamous cell carcinoma."

In addition, the legend of Figure 2 is incorrect:

"Squamous cell epithelium positive for p16 immunohystochemical staining at 40x magnification. Histological section originates from a grade 3 tonsillar squamous cell carcinoma."

should read:

"Squamous cell epithelium negative for p16 immunohistochemical staining at 40x magnification. Histological section originates from a grade 2 oropharyngeal wall squamous cell carcinoma."

(i) Open Access This article is licensed under a Creative Commons Attribution 4.0 International License, which permits use, sharing, adaptation, distribution and reproduction in any medium or format, as long as you give appropriate credit to the original author(s) and the source, provide a link to the Creative Commons license, and indicate if changes were made. The images or other third party material in this article are included in the article's Creative Commons license, unless indicated otherwise in a credit line to the material. If material is not included in the article's Creative Commons license and your intended use is not permitted by statutory regulation or exceeds the permitted use, you will need to obtain permission directly from the copyright holder. To view a copy of this license, visit http://creativecommons.org/licenses/by/4.0/.

(C) The Author(s) 2020 